\author{
N.I. Yermoshin, E.V. Yakimov, A.E. Goldshtein \\ National Research Tomsk Polytechnic University, Russia \\ (E-mail: ermoschin.nik@yandex.ru)
}

\title{
Double-channel resistance-to-voltage converter for cable teraohmmeters
}

\begin{abstract}
The paper considers a teraohmmeter resistance converter to monitor cable insulation with an additional input amplifier that emits a low-frequency interference signal. Adaptive algorithms for a double-channel converter circuit to compensate for low-frequency interference are proposed. There are considered algorithms using minimax criteria and linear approximation method for estimation of interference influence. It is shown classification of algorithms according to industrial frequency interference filtering method and signal observation interval. There were investigated two ways of interference application: step signal from a DC voltage source up to $300 \mathrm{~V}$ and fading harmonic signal from an $\mathrm{AC}$ voltage source and amplifier up to $300 \mathrm{~V}$. A doublechannel circuit of the resistance-to-voltage converter is found to provide a 2 -fold increase in the signal-tonoise ratio in comparison with a single-channel circuit. It is shown that the maximum deviation of readings for the single-channel circuit exceeds $20 \%$ (up to $32 \%$ ) in short-term exposure to interference with amplitude of up to $300 \mathrm{~V}$. At the same time, the maximum deviation for the double-channel circuit can attain $17 \%$, but it does not exceed $20 \%$. According to GOST 3345-76, the insulation resistance measuring error in the range of $10 \mathrm{G} \Omega$ to $100 \mathrm{~T} \Omega$ should not exceed $20 \%$. The advantage of the proposed double-channel converter is the possibility to develop new algorithms to eliminate the dependence of readings on interference effects.
\end{abstract}

Keywords: insulation resistance, cable, interference, resistance-to-voltage converter, teraohmmeter.

\section{Introduction}

A number of problems arising during monitoring the cable insulation quality by electrical resistance are associated with a large value of the measured resistance. One of the most important problems is the sensitivity of the input circuits of the measuring device (teraohmmeter) to low-frequency interference [1-6], which occurs during mutual movement of electrostatic charges that accumulate on the surface of the measuring device, cable and operator.

The techniques to eliminate this kind of interference are the use of shields, ESD straps for the operator, interference filtering, and the current level in the input circuit of the device increased through an increase in the voltage applied to the cable [7-13]. However, these measures are not always adequate. For example, large coils with cable may require large shields, which limit test equipment mobility. ESD straps are effective, but poorly trained personnel can ignore the need for its use. In addition, this binds the operator to the device like a prisoner. An increase in voltage applied to the cable is limited since the maximum allowable voltage for a given cable is specified in the cable documentation. The voltage level used by the teraohmmeter may provide inaccurate measurement of the insulation resistance [14-19]. Interference filtering typically increases the device inertia. Therefore, in case of low-frequency interference (less than $1 \mathrm{~Hz}$ ), linear filtering is of little use: the time for processing the readings becomes comparable or longer than the time permissible for recording the readings of the device.

Thus, development of methods to eliminate the impact of low-frequency interference on the teraohmmeter input circuit while maintaining low values of the test voltage (according to GOST 3345-76 from 100 to $1000 \mathrm{~V}$ ) is of current relevance.

The paper considers a method of compensating for low-frequency interference that uses an additional channel in the cable teraohmmeter along with the main resistance-to-voltage converter (RVC), which responds to interference signal only. Signals of the primary and secondary channels can be processed in accordance with various algorithms; therefore, a compensation algorithm can be chosen to provide low sensitivity to interference.

\section{Experimental}

Figure 1 shows a diagram of the double-channel RVC and the impact produced on it by the operator during monitoring of the cable insulation resistance. 


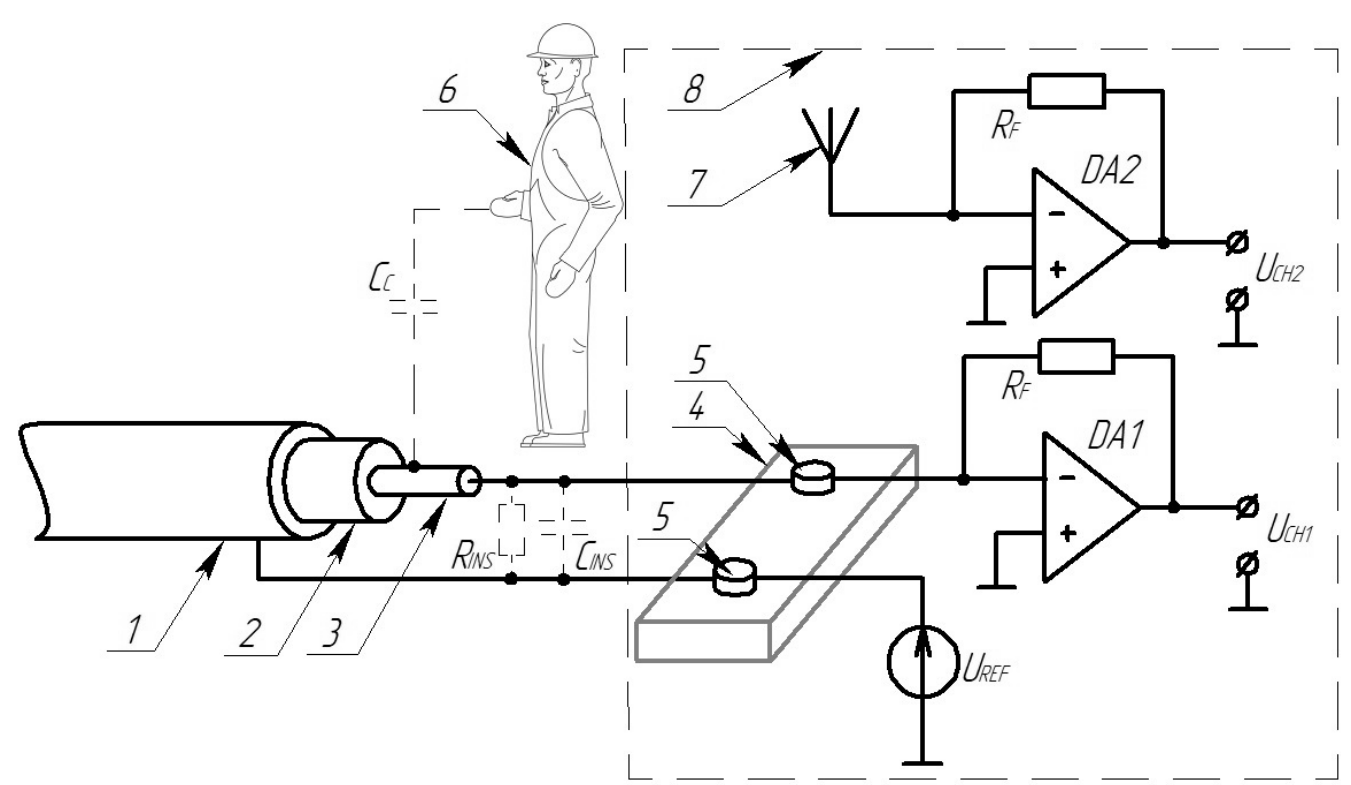

1 - is the cable shielding; 2 - is the cable insulation material; 3 - is the conductive cable core;

4 - is the block for electrodes; 5 - is the electrodes to connect the controlled cable to RVC; 6 - is the operator monitoring the cable insulation resistance; 7 - is the antenna;

8 - is the RVC; $C_{C}$ - is the communication capacity between the operator and cable;

$R_{I N S}, C_{I N S}$ - is the resistance and capacity of cable insulation; $U_{R E F}$ - is the reference voltage source;

$R_{F}$ - is the negative feedback resistance; $U_{C H 1}, U_{C H 2}$ - are output voltage of the first and second RVC measuring channels; $D A 1, D A 2$ - are operational amplifiers

Figure 1. An equivalent diagram of the operator's impact during monitoring of the cable insulation resistance

The reference voltage source $U_{R E F}$ and the measured cable insulation resistance $R_{I N S}$ form an artificial current generator. The load of the current generator is a negative feedback reference resistor $R_{F}$. The voltage drop in the resistor in steady state is:

$$
U_{I N S}=-\frac{R_{F}}{R_{I N S}} \cdot U_{R E F},
$$

where $U_{I N S}$ is the voltage drop across the measured cable insulation resistance.

The output signal of the first measuring channel takes the form:

$$
U_{C H 1}=U_{I N S}+U_{I F 1} \cdot \sin \left(2 \cdot \pi \cdot f_{I F} \cdot \mathrm{t}+\varphi_{I F 1}\right)+U_{L F 1} \cdot \sin \left(2 \cdot \pi \cdot f_{L F} \cdot \mathrm{t}+\varphi_{L F 1}\right)
$$

where $U_{I F 1}$ is the voltage amplitude of industrial frequency interference; $t$ is time; $f_{I F}$ is the voltage frequency of industrial frequency interference; $\varphi_{I F 1}$ is the initial phase of the voltage of industrial frequency interference; $U_{L F 1}$ is the voltage amplitude of low-frequency interference; $f_{L F}$ is the voltage frequency of low-frequency interference; $\varphi_{L F 1}$ is the initial phase of the voltage of low-frequency interference.

The signal from the antenna is supplied to the input of the operational amplifier DA2 and contains data on interference only. The output signal in the second measuring channel takes the form:

$$
U_{C H 2}=U_{I F 2} \cdot \sin \left(2 \cdot \pi \cdot f_{I F} \cdot \mathrm{t}+\varphi_{I F 2}\right)+U_{L F 2} \cdot \sin \left(2 \cdot \pi \cdot f_{L F} \cdot \mathrm{t}+\varphi_{L F 2}\right),
$$

where $U_{I F 2}$ is the voltage amplitude of industrial frequency interference picked by antenna; $\varphi_{I F 2}$ is the initial phase of the voltage of industrial frequency interference picked by antenna; $U_{L F 2}$ is the voltage amplitude of low-frequency interference picked by antenna; $\varphi_{L F 2}$ is the initial phase of the voltage of lowfrequency interference picked by antenna.

The interference voltage at the outputs of the first and second measuring channels is of similar frequency, but of different amplitude and phase. 
To obtain data on the measured insulation resistance only, an adaptive signal processing algorithm is required for real-time selection of the coefficients $k_{1}, k_{2}$ and the phase shifts $\Delta \varphi_{I F}, \Delta \varphi_{L F}$ of the output signal in the second measuring channel relative to the output signal in the first measuring channel:

- $k_{1}=\frac{U_{I F 1}}{U_{I F 2}}$ is the coefficient that estimates the ratio of the voltage amplitude of industrial frequency interference in the first measuring channel to that in the second measuring channel;

- $k_{2}=\frac{U_{L F 1}}{U_{L F 2}}$ is the coefficient that estimates the ratio of the voltage amplitude of low-frequency interference in the first measuring channel to that in the second measuring channel;

- $\Delta \varphi_{I F}=\varphi_{I F 1}-\varphi_{I F 2}$ is the phase shift of the voltage of industrial frequency interference between the first and second measuring channels;

- $\Delta \varphi_{L F}=\varphi_{L F 1}-\varphi_{L F 2}$ is the phase shift of the voltage of low-frequency interference between the first and second measuring channels.

As a result, it becomes possible to compensate for low-frequency interference and industrial frequency interference:

$$
U_{I N S}=U_{C H 1}-\left[k_{1} \cdot U_{I F 2} \cdot \sin \left(2 \cdot \pi \cdot f_{I F} \cdot \mathrm{t}+\varphi_{I F 2}-\Delta \varphi_{I F}\right)+k_{2} \cdot U_{L F 2} \cdot \sin \left(2 \cdot \pi \cdot f_{L F} \cdot \mathrm{t}+\varphi_{L F 2}-\Delta \varphi_{L F}\right)\right] .
$$

At different ranges of the insulation resistance measurement, the coefficients $k_{1}, k_{2}$ and the phase shifts $\Delta \varphi_{L F}, \Delta \varphi_{I F}$ are not constant. In addition, they can vary against the signal level, therefore, it is sufficiently difficult to find a circuitry solution (based on analog electronic circuits or digital circuits with rigid logic) for real-time selection of the coefficients $k_{1}, k_{2}$ and the phase shifts $\Delta \varphi_{L F}, \Delta \varphi_{I F}$. Digital signal processing by means of microprocessors, when algorithms can be quickly changed through reprogramming, provides a more flexible approach to problem solution.

To perform digital processing, the signals $U_{C H 1}$ and $U_{C H 2}$ must be converted using the ADC.

There are many signal processing options to compensate for interference.

Algorithm with Minimum and Maximum Deviations. Figure 2 shows an example of an adaptive signal processing algorithm in which the value of the coefficient $k_{2}$ is estimated by the minimum and maximum values of the signals $U_{C H 1}$ and $U_{C H 2}$. This algorithm diagram shows the paths of signal transmission and conversion as structural blocks in a language similar to the LabView graphical programming language, i.e. arrows indicate signals, and rectangles indicate transformation blocks.

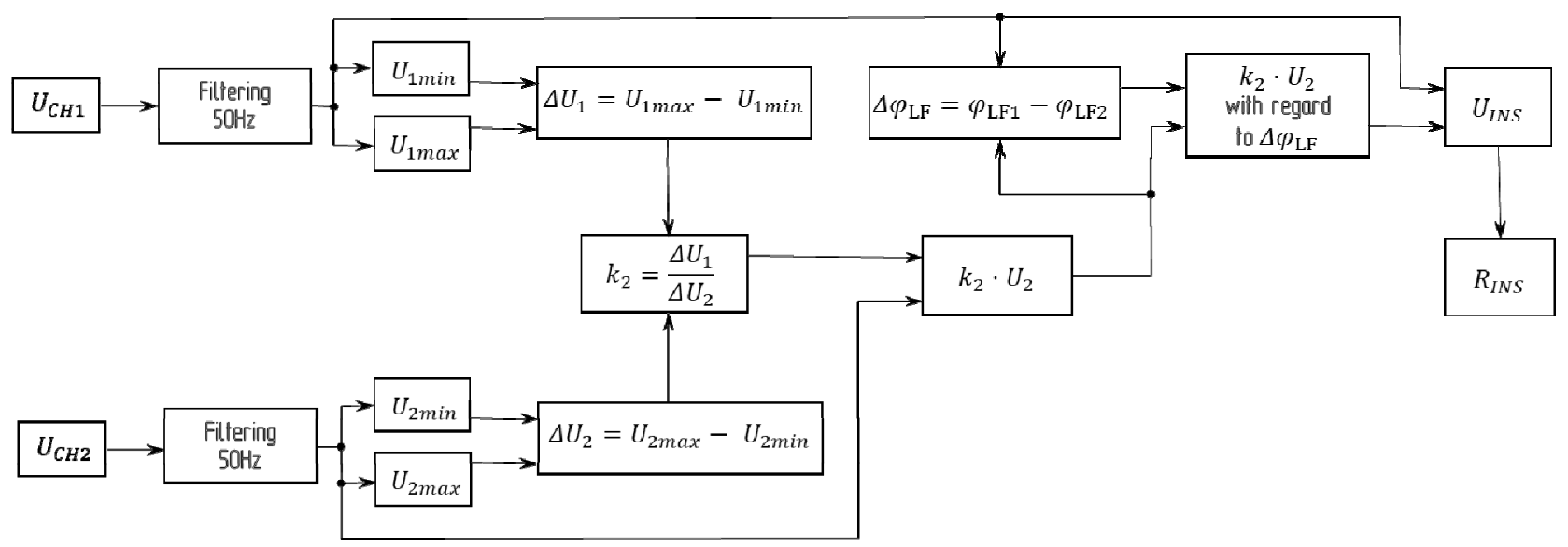

Figure 2. Adaptive signal processing algorithm with the minimum and maximum values of the signals $U_{\mathrm{CH} 1}$ and $U_{\mathrm{CH} 2}$ to estimate the coefficient $k_{2}$

The algorithm works as follows.

The output voltage from the first and second measuring channels is filtered from industrial frequency interference $f_{I F}=50 \mathrm{~Hz}$. The coefficient $k_{1}$ and the phase shift $\Delta \varphi_{I F}$ are not estimated in this operation, which greatly simplifies further signal processing. 
The signals $U_{1}$ and $U_{2}$ filtered from industrial frequency interference are supplied to blocks in which the minimum and maximum values are estimated. The ratio of the difference between the signal maximum and minimum values, and the difference between the maximum and minimum values of the signal $U_{1}$ allows estimation of the coefficient $k_{2}$ (it is assumed that $\Delta U_{1}=\Delta U_{L F 1}$ and $\Delta U_{2}=\Delta U_{L F 2}$ ).

After that, the signal $U_{2}$ filtered from industrial frequency interference in the second measuring channel is multiplied by the coefficient $k_{2}$.

This signal and the signal $U_{1}$ filtered from industrial frequency interference in the first measuring channel are supplied to the block, in which the phase shift $\Delta \varphi_{L F}=\varphi_{L F 1}-\varphi_{L F 2}$ is estimated.

Taking into account the phase shift $\Delta \varphi_{L F}$ and the coefficient $k_{2}$, the signal of the second measuring channel is subtracted from the signal of the first measuring channel in accordance with Equation (2). As a result, the remaining signal depends only on the voltage $U_{I N S}$. After that, Equation (1) can be used to calculate the cable insulation resistance:

$$
R_{I N S}=\frac{R_{F}}{U_{I N S}} \cdot U_{R E F} .
$$

Algorithm with linear approximation. Similarly, adaptive signal processing can be performed using linear approximation to determine the coefficient $k_{2}$ instead of the minimum and maximum deviations from the average signal value.

Figure 3 shows an example of this algorithm.

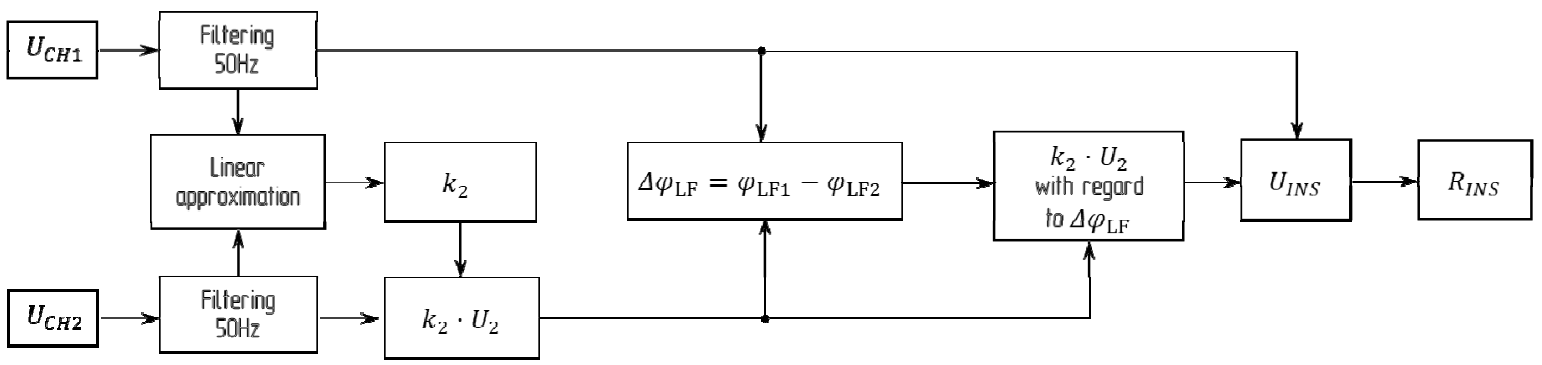

Figure 3. Adaptive signal processing algorithm with linear approximation to estimate the coefficient $k_{2}$

The output voltage in the first and second measuring channels is filtered from $50 \mathrm{~Hz}$ industrial frequency interference similar to that in the algorithm presented in Figure 2. After that, the signals are supplied to the linear approximation block. At the block output, the coefficient is estimated. The following sequence of operations of the signal processing algorithm does not differ from the algorithm shown in Figure 2.

The signal processing interval and the method of filtering industrial frequency interference can be varied in the algorithms presented in Figures 2 and 3. Figure 4 shows the classification of possible adaptive signal processing algorithms for the double-channel RVC circuit.

The algorithm operation speed and the quality of interference suppression depend on the signal processing interval. The signal processing interval should not exceed $1-2 \mathrm{~s}$, which will allow the device to timely update measurement readings. In addition, signal splitting into short segments or signal analysis within the entire interval stored in the memory can be used to estimate signal parameters and to compensate for interference.

Industrial frequency interference can be filtered using: $50 \mathrm{~Hz}$;

1) linear low-pass filters (Butterworth, Chebyshev, Bessel) with a cutoff frequency not exceeding

2) subtraction of the signal $U_{I F}$ of industrial frequency interference similar to subtraction of the signal $U_{L F}$ of low-frequency interference in adaptive selection of the coefficient $k_{1}$ and the phase shift $\Delta \varphi_{I F}$.

The algorithm of adaptive signal processing with linear approximation can employ several variations of the linear approximation method to determine the coefficient $k_{2}$. The least square method should be used for data with normally distributed interference, whereas the least absolute residual and bisquare methods can be employed in case of data outliers [20]. 


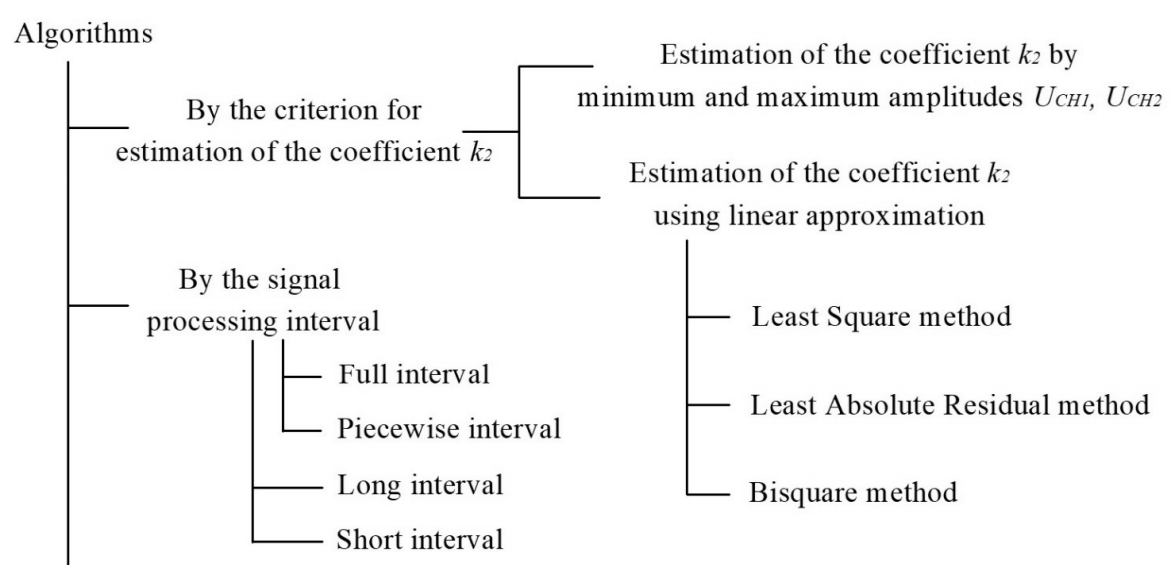

By the interference filtering method $f_{I F}$

$$
\begin{aligned}
& \text { Linear low-pass filters } \\
& \text { Adaptive selection } k_{I}
\end{aligned}
$$

Figure 4. Classification of adaptive signal processing algorithms for the double-channel RVC circuit

The variety of digital signal processing algorithms and the dependence of algorithms on different characteristics of RVC and ADC make it possible to extend the list of algorithm options presented in Figure 4 as new studies become available.

The installation to generate low-frequency interference was designed in order to investigate interference immunity of the double-channel RVC while monitoring the cable insulation resistance (Fig. 5). The installation consists of the following units:

1) DC voltage source of up to $300 \mathrm{~V}$;

2) GW Instek SFG-2104 function generator to generate a low-frequency signal;

3) an amplifier to amplify the signal from the generator up to $300 \mathrm{~V}$;

4) an electrode in the form of a metal cylinder to which an amplified low-frequency signal is supplied.

As a result, the electrode generated an alternating electric field of low frequency (low-frequency interference) with an output voltage ranging from 0 to $300 \mathrm{~V}$. In the experiment, the electrode base was located at the distance $r$ from the inverting input of the RVC operational amplifier.

All studies were carried out in a shielding chamber to objectively assess the effect of artificially generated interference (low-frequency electric field), since the impact of external interference inside the shielding chamber was minimized.

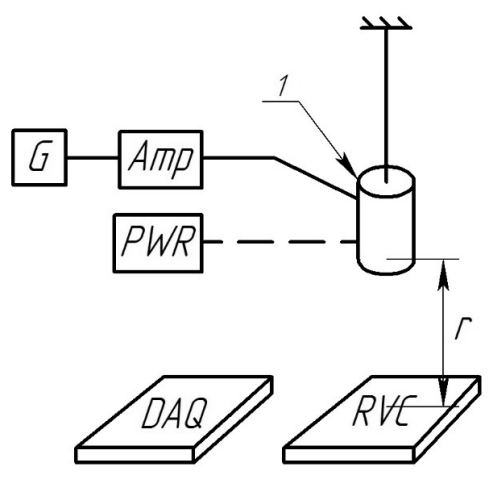

1 - is the electrode; $G$ - is the generator; $A m p$ - is the amplifier; $P W R$ - is DC voltage source; $R V C$ - is the resistance-to-voltage converter; $D A Q$ - is the data acquisition board

Figure 5. Diagram of the electrode charge

Low-frequency interference was artificially generated through the short-term $(<1 \mathrm{~s})$ voltage supply to the electrode to simulate the impact of an operator monitoring the cable insulation resistance on the CVS. The voltage was supplied to the electrode in two ways: from a DC voltage source or from an AC voltage source. A short-term exposure is chosen in order to create a non-periodic damping interference signal. Due to 
this effect, a constant component is introduced into the RVC signal, which cannot be filtered from the output RVC signal using averaging methods. circuits.

The circuitry of the double-channel RVC enables simultaneous study of the single- and double-channel

The output voltage of the first measuring channel was used to assess interference immunity of the single-channel RVC circuit. This signal was filtered from industrial frequency interference by digital processing using a second-order linear Butterworth filter with a cut-off frequency of $30 \mathrm{~Hz}$ and was then averaged. The average signal value was used to measure the resistance in accordance with Equation (3).

Signals of the double-channel RVC circuit were digitally processed in accordance with the algorithm presented in Figure 2. Industrial frequency interference was filtered similarly to the single-channel RVC circuit. Resistance converters were implemented in accordance with the T-shaped circuit shown in [21, 22]. The converter characteristics were as follows: voltage reference $U_{R E F}=100 \mathrm{~V}$; feedback resistance of the amplifier $R_{F}=1 \mathrm{G} \Omega$; capacitor capacity in the integrator $C=50 \mathrm{pF}$; the measured resistance is five seriesconnected resistors of the type KVM-100 G $\Omega \pm 10 \%$.

Digital signal processing was performed using the USB-6002 multifunctional data acquisition device ( 8 channels, 16 bits, $50 \mathrm{kHz}$ ). The LabView programming environment was used for signal processing.

\section{Results and Discussion}

Figure 6 shows the output signals of the single- and double-channel RVC circuits in short-term exposure of the electrode to DC voltage of $200 \mathrm{~V}$.

a)

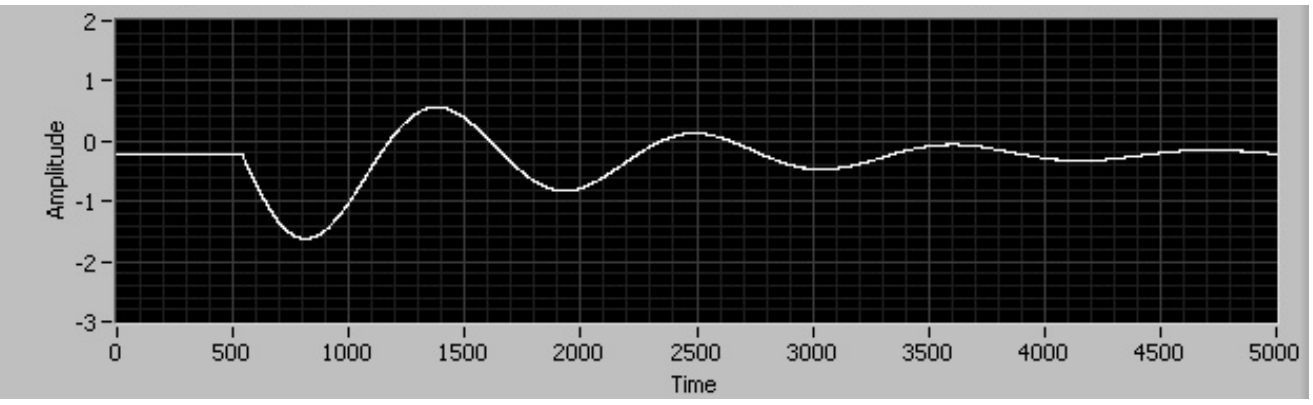

b)

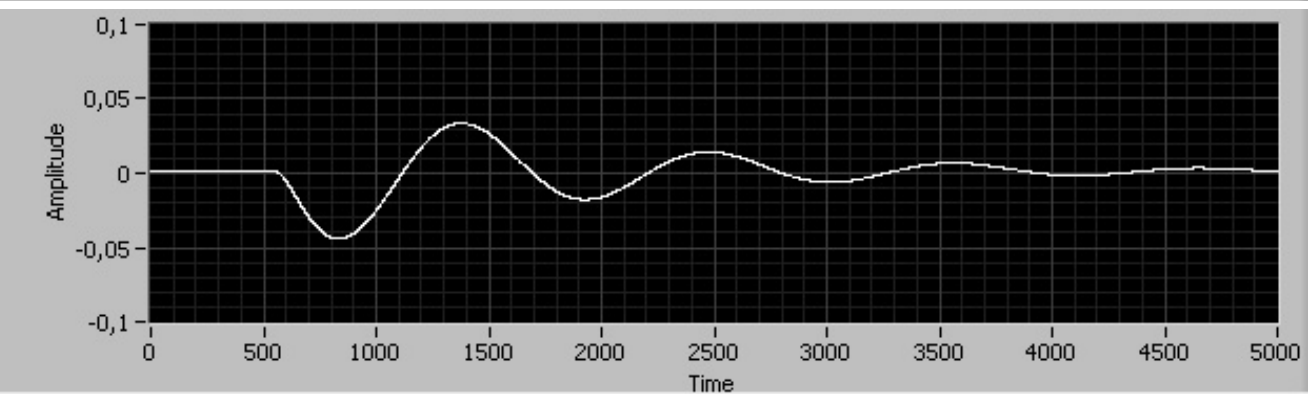

c)

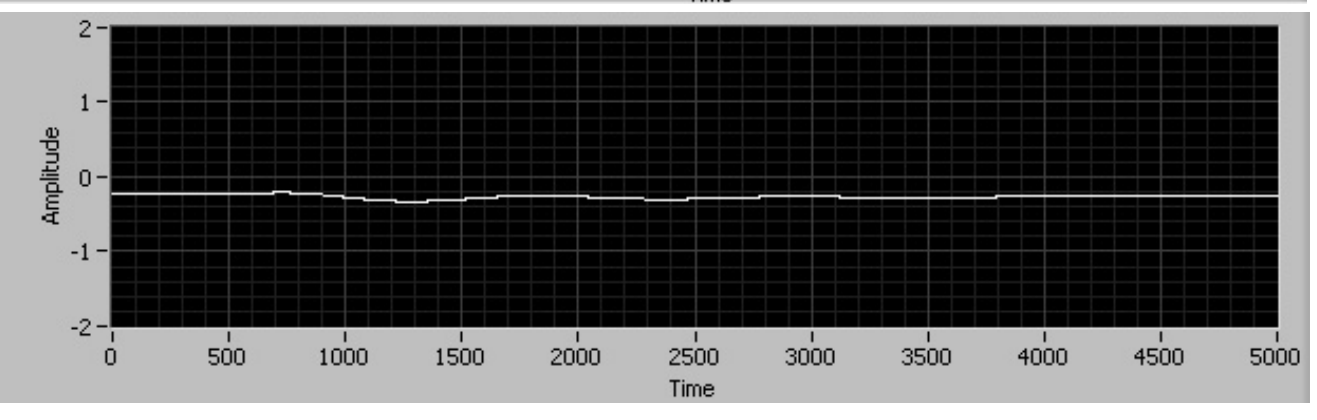

$a$ - output voltage of the single-channel RVC circuit; $b$ - output voltage $U_{\mathrm{CH}_{2}}$ of the second measuring channel of RVC; $c$ - output voltage $U_{I N S}$ of the double-channel RVC circuit

Figure 6. The output signals of the single- and double-channel RVC circuits during short-term exposure of the electrode to DC voltage of $200 \mathrm{~V}$ 
The comparison of Figures $6 a$ and $6 b$ indicates similarity of the shape and frequency $f_{L F}$ of lowfrequency interference captured by the first and second measuring channels. The phase shift $\Delta \varphi_{L F}$ between the first and second measuring channels can be observed as well. After adaptive selection of the coefficient $k_{2}$, the signals are subtracted. Figure $6 \mathrm{c}$ presents the result of subtracting the signal $U_{\mathrm{CH}_{2}}$ from the signal $U_{C H 1}$, which is an output voltage of the double-channel RVC circuit.

The maximum deviation of the system readings affected by interference from the average value of the resistance measured in the absence of interference was estimated during signal processing. The maximum deviation for the single-channel circuit was $25 \%$, and that for the double-channel circuit equaled $14 \%$.

With short-term exposure of the electrode to DC voltage of $300 \mathrm{~V}$, the maximum deviation for the single-channel circuit was $32 \%$, and that for the double-channel circuit was $17 \%$.

The obtained results show that the maximum deviation of readings increases as the interference amplitude grows up.

Figure 7 shows the output signals of the single- and double-channel RVC circuits during short-term exposure of the electrode to $\mathrm{AC}$ voltage with $300 \mathrm{~V}$ amplitude and $2 \mathrm{~Hz}$ frequency.

a)

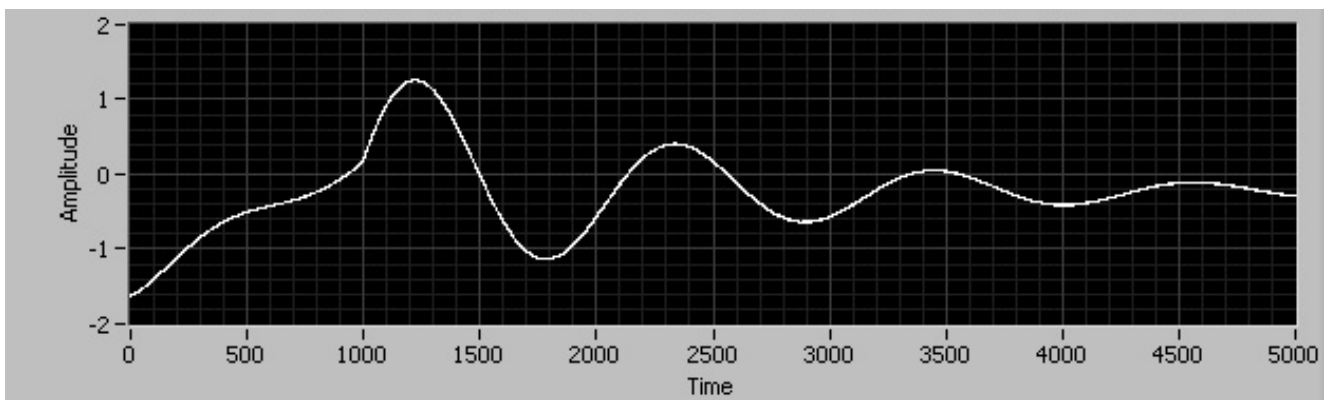

b)

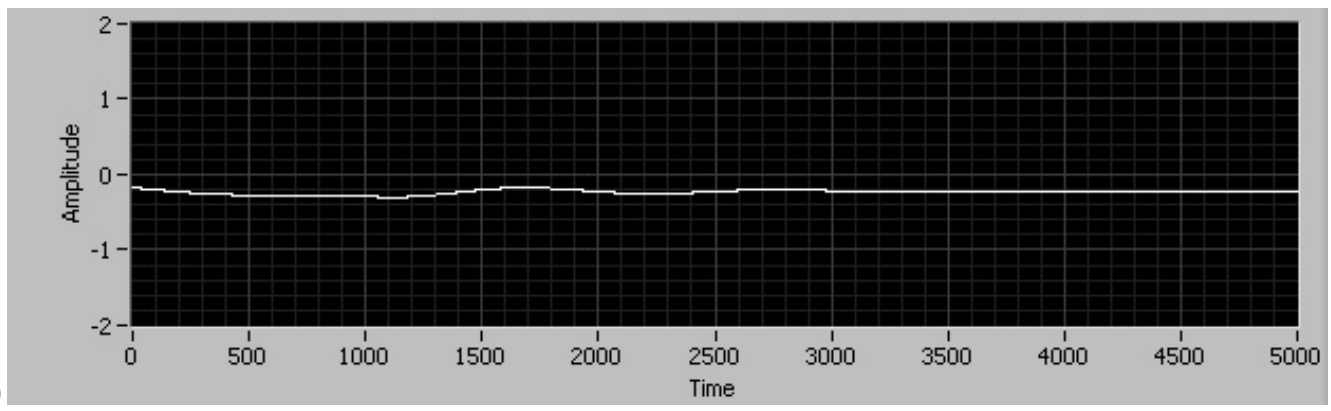

$a$ - output voltage of the single-channel RVC circuit; $b$ - output voltage of the double-channel RVC circuit

Figure 7. The output signals of the single- and double-channel RVC circuits during short-term exposure of the electrode to $\mathrm{AC}$ voltage with $300 \mathrm{~V}$ amplitude and $2 \mathrm{~Hz}$ frequency

The maximum deviation of readings for the single-channel circuit was $11 \%$, and that for the doublechannel circuit was $5 \%$.

Figure 8 shows the output signals of the single- and double-channel RVC circuits during short-term exposure of the electrode to AC voltage with $300 \mathrm{~V}$ amplitude and $5 \mathrm{~Hz}$ frequency.

The maximum deviation of readings for the single-channel circuit was $78 \%$, and that for the doublechannel circuit equaled $3.5 \%$. 
a)

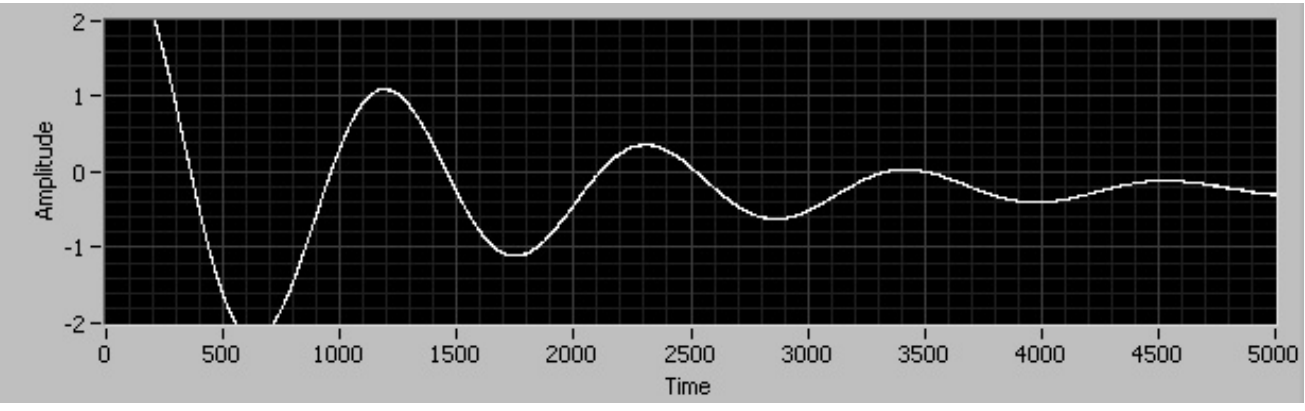

b)

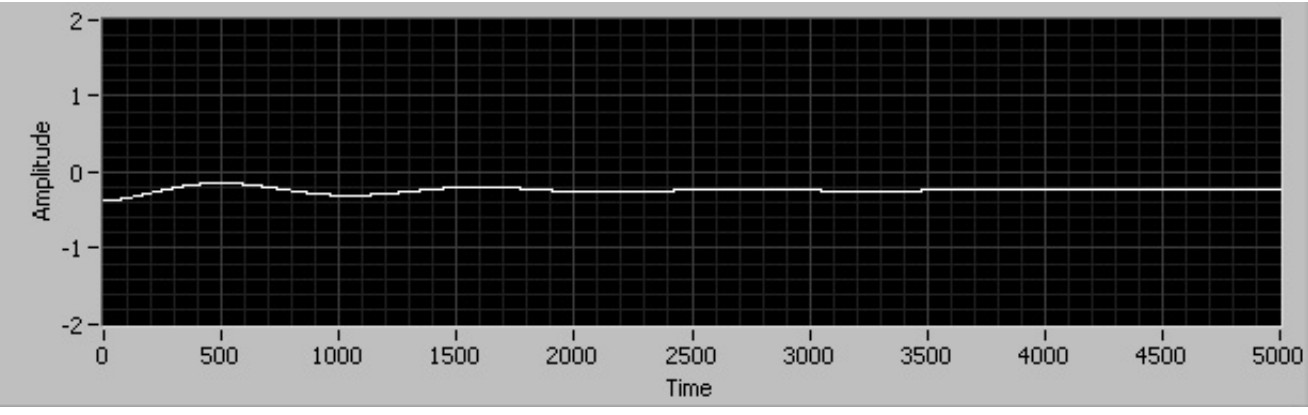

$a$ - output voltage of the single-channel RVC circuit; $b$ - output voltage of the double-channel RVC circuit

Figure 8. The output signals of the single- and double-channel RVC circuits during short-term exposure of the electrode to AC voltage with $300 \mathrm{~V}$ amplitude and $5 \mathrm{~Hz}$ frequency

\section{Conclusion}

According to GOST 3345-76, the insulation resistance measuring error in the range of $10 \mathrm{G} \Omega$ to $100 \mathrm{~T} \Omega$ should not exceed $20 \%$. The results obtained in the experimental study of the single- and doublechannel circuits of resistance-to-voltage converters show that the maximum deviation of readings for the single-channel circuit exceeds $20 \%$ (up to $32 \%$ ) in short-term exposure to interference with amplitude of up to $300 \mathrm{~V}$. At the same time, the maximum deviation for the double-channel circuit can attain $17 \%$, but it does not exceed $20 \%$. Thus, the signal-to-noise ratio for the double-channel circuit is almost twice higher than that for the single-channel circuit.

The advantage of the proposed double-channel converter is the possibility to develop new algorithms to eliminate the dependence of readings on interference effects.

The research is funded by the Governmental program «Science», research projects No. 11.3683.2017/4.6, No.11.6342.2017/8.9, FSWW-2020-0014.

The research is carried out within the framework of Tomsk Polytechnic University Competitiveness Enhancement Program grant, the Project number is VIU-IShNKB-77/2019.

\section{References}

1 Yermoshin, N.I., Yakimov, E.V., \& Goldshtein, A.E. (2019). Study of the effect of low-frequency interference on Resistance-to-Voltage Converter in cable insulation testing. Materials Science Forum: Modern Problems in Materials Processing, Manufacturing, Testing and Quality Assurance II, 970, 297-304.

2 Vavilova, G.V., \& Ryumkin, A.V. (2018). Detection of insulation defects in the wire through measuring changes in its capacitance. IOP Conference Series: Materials Science and Engineering, 289, 012017(1-6). doi: 10.1088/1757-899X/289/1/012017.

3 Rietveld, G., Jarrett, D., \& Jeckelmann, B. (2014). Accurate high-ohmic resistance measurement techniques up to $1 \mathrm{P} \mu$. CPEM Digest (Conference on Precision Electromagnetic Measurements), 6898373, 290-291. doi: 10.1109/CPEM.2014.6898373.

4 Chursin, Y.A., Redko, L.A., \& Fedorov, E.M. (2019). Enlargement of measuring zone in laser gauges without sacrificing measurement accuracy. Measurement, 131, 647-653. doi: 10.1016/j.measurement.2018.09.031.

5 Tu, Y., Gong, B., Wang, C., Xu, K., Xu, Z., Wang, S., et al. (2015). Effect of moisture on temperature rise of composite insulators operating in power system. IEEE Transactions on Dielectrics and Electrical Insulation, 22, $2207-2213$. doi: 10.1109/TDEI.2015.004696.

6 Semenov, D., Sidorova, A., Romanov, P., \& Kuvshinov, A. (2018). Examination of State of the Cable Insulation by the Return Voltage. International Journal of Emerging Electric Power Systems, 19(6), 1-10. doi: 10.1515/ijeeps-2018-0167. 
7 Sawhney, A. (1985). A course in Electrical and Electronic Measurements and Instrumentation. NaiSarak: Dhanpat rai \& sons.

8 Malaric, R. (2011). Instrumentation and Measurement in Electrical Engineering. New York: BrownWalker Press.

9 Tumanski, S. (2006). Principles of Electrical Measurement. New York: Taylor \& Francis.

10 Honig, R. (2010). Practical Aspects of High Resistance Measurement. Measurements International, 19-25.

11 Jarret, D. (1997). Automated guarded bridge for calibration of multimegohm standard resistors from $10 \mathrm{MOhm}$ to $1 \mathrm{TOhm}$. IEEE Trans. Instrum. Meas., 46 (2), 325-328.

12 Rietveld, G., \& Van der Beek, J. (2012). Active-arm resistance bridge with voltage null-detection for precision measurement of resistances above $1 \mathrm{MOhm}$. CPEM2012 Conference Digest, 199-200.

$13 \mathrm{Kim}, \mathrm{K}-\mathrm{T}$., \& Yu, K-M. (2009). A new method for insulation resistance measurement at low voltage level using change of effective resistance. XIX IMECO World Congress Fundamental and Applied Metrology, 958-959.

14 Noda, T., Nakamatsu, T., \& Mekaru, T. (2014). Measurement of cable resistance at high frequencies. IEEJ Transactions on Electrical and Electronic Engineering, 10, 112-113.

15 Ghajar, Mashhadi, M., Irannejad, M., Yavuz, M., \& Abdel-Rahman, E. (2018). Effects of static electricity and fabrication parameters on PVDF film properties. Bulletin of Materials Science, 41-43.

16 Mao, H., Ma, P., \& Jiang, G. (2018). Electrostatic and mechanical properties of extrusion spun PTFE monofilament with integration of microtourmaline particles. Journal of Applied Polymer Science, 135, 1-7.

17 Copuroglu, E., \& Mehmetoglu, T. (2019). Analytical evaluation of the Uehling potential using binomial expansion theorems. Bulletin of the Karaganda University. Physics series, 3(95), 17-21, doi: 10.31489/2019Ph3/17-21.

18 Yong, S., Hosseinberg, S., Yang, S., Heaney, M., \& Pommerenke, D. (2018). Noncontact human body voltage measurement using Microsoft Kinect and Field Mill for ESD applications. IEEE Transactions on Electromagnetic Compatibility, 1-10.

19 Vorsheyskii, A., \& Grishakov, E. (2017). The Influence of Electrostatic Charge on the Stability of Electronic and Electrical Equipment. Russian Electrical Engineering, 88, 805-809.

20 Shiralkar, M. (2007). LabVIEW Graphical Programming Course. Houston: National Instruments.

21 Yermoshin, N.I., \& Yakimov, E.V. (2018). Feasibility of using T-shaped feedback in teraohmmeters. IOP Conference Series: Materials Science and Engineering, 289, 1-7. doi: 10.1088/1757-899x/289/1/012008.

22 Khaydarov, B. K., Makarov, V. P., \& Khaydarov, K. (2018). Composite stratified-hardened containers for synthesis of diamond polycrystals of a type carbonado, Bulletin of the Karaganda University. Physics series, 4(92), 101-106.

\title{
Н.И. Ермошин, Е.В. Якимов, А.Е. Голдштейн
}

\section{Кабелді тераомметрлерге арналған кернеуге екі арналы кедергі түрлендіргіш}

\begin{abstract}
Мақалада аз жиілікті бөгеуіл сигналын бөлетін қосымша кіріс күшейткіші бар кабель оқшаулауын бақылау үшін тераомметрдің кедергі түрлендіргішінің сұлбасы қарастырылған. Төмен жиілікті бөгеуілдердің орнын толтыруға мүмкіндік беретін түрлендіргіштің екі арналы сұлбасы үшін бейімделген алгоритмдер ұсынылған. Сонымен қатар, кедергілердің әсерін бағалау кезінде минимакстық критерийі, сондай-ақ сызықтық аппроксимация әдісін пайдаланатын алгоритмдер қарастырылған. Өнеркәсіптік жиілік кедергілерін сүзу әдісі бойынша және дабылдарды өңдеу интервалы бойынша алгоритмдерді жіктеу берілген. Кедергінің әсерінің екі түрі зерттелген: амплитудамен 300 В тұрақты кернеу көзінің сатылы әсері және күшейткішпен 300 В дейін айнымалы кернеу генераторынан өшетін гармоникалық әсері. Бір арналы сұлба үшін көрсеткіштердің ең жоғары ауытқуы 20 \%-дан (32 \%-ға дейін) асатын уақытта, екі арналы сұлба үшін ең жоғары ауытқу 17 \%-ға жетуі мүмкін, бірақ $20 \%$-дан аспайды. МЕМСТ 3345-76 сәйкес 10 ГОм-дан 100 Том-ға дейінгі диапазонда оқшаулама кедергісін өлшеу қателігі 20\% аспауы тиіс. Ұсынылған екі арналы түрлендіргіштің артықшылығы - кедергілердің әсеріне тәуелділігін төмендететін жаңа алгоритмдерді әзірлеуді жалғастыруға болады.
\end{abstract}

Кілт сөздер: оқшаулау кедергісі, кабель, кедергі, кернеу түрлендіргіші, тераомметр.

\section{Н.И. Ермошин, Е.В. Якимов, А.Е. Гольдштейн \\ Двухканальный преобразователь сопротивления в напряжение для кабельных тераомметров}

В статье рассмотрена схема преобразователя сопротивления тераомметра для контроля изоляции кабеля с дополнительным входным усилителем, который выделяет низкочастотный сигнал помехи. Предложены адаптивные алгоритмы для двухканальной схемы преобразователя, позволяющие произвести компенсацию низкочастотных помех. При этом рассмотрены алгоритмы, использующие при оценке влияния помех минимаксный критерий, а также метод линейной аппроксимации. Дана клас- 
сификация алгоритмов по методу фильтрации помех промышленной частоты и по интервалу обработки сигналов. Исследованы два вида воздействия помех: ступенчатое воздействие от источника постоянного напряжения амплитудой до $300 \mathrm{~B}$ и затухающее гармоническое воздействие от генератора переменного напряжения с усилителем до 300 В. Определено, что при использовании двухканальной схемы преобразователя сопротивления в напряжение отношение сигнал-шум увеличивается в 2 раза по сравнению с одноканальной схемой. Установлено, что в то время, как максимальное отклонение показаний для одноканальной схемы превышает 20 \% (до 32 \%), для двухканальной схемы может достигать $17 \%$, но не превышает порога $20 \%$. В соответствии с ГОСТ-ом 3345-76 погрешность измерения сопротивления изоляции в диапазоне от 10 ГОм до 100 ТОм не должна превышать $20 \%$. Достоинством предложенного двухканального преобразователя является то, что можно продолжить разработку новых алгоритмов, которые позволят уменьшить зависимость показаний от влияния помех.

Ключевые слова: сопротивление изоляции, кабель, помеха, преобразователь сопротивления в напряжение, тераомметр. 